ISSN 1978 - 3000

\title{
Korelasi Genetik dan Fenotipik Produksi Susu Laktasi Pertama dengan Daya Produksi Susu Sapi Fries Holland
} \author{
ability for Fries Holland cows \\ Dadang Suherman \\ Jurusan Peternakan Fakultas Pertanian Universitas Bengkulu \\ Jalan Raya Kandang Limun. Telp. (0736) 21170. Pst. 219.
}

Genetic and phenotypic correlation between first lactating milk production and milk production

\begin{abstract}
The aim of the study was to investigate milk production during first lactation, milk production ability, and genetic and phenotypic correlation between first lactating milk production and milk production ability. Data were collected from the milk production record for first, second, third, and forth lactation of 161 lactating cows in which they were mated with 20 Fries Holland bull. Data of milk production were then standardized and adjusted to 305 days milking, two milking per-day, and age or maturity equivalent. The research method was comparative method, in which data was calculated for repeatability estimation of milk production using intra class correlation. Milk production repeatability was then used for estimating milk production ability using Lush (1979) formula. Genetic and phenotypic correlation between first lactating milk production and milk production ability was calculated using variance and covariance of one way lay out paternal half sib model. Results showed that the total averages of milk production at first lactation was $2.919,04 \mathrm{Kg}$, repeatability value of 0.41 , mean milk production ability was $2.920,23 \mathrm{Kg}$, and genetic and phenotypic correlation between first lactating milk production and milk production ability was 0,89 and 0,76 respectively.
\end{abstract}

Key words : Genetic correlation, phenotypic correlation, first lactation.

\begin{abstract}
ABSTRAK
Tujuan penelitian ini adalah untuk mengetahui besarnya produksi susu laktasi pertama, daya produksi susu, serta nilai korelasi genetik dan fenotipik antara produksi susu laktasi pertama dengan daya produksi susu. Data yang dianalisis berupa catatan produksi susu laktasi pertama, kedua, ketiga, dan keempat dari 161 ekor sapi perah betina keturunan 20 ekor pejantan Fries Holland. Sebelum dianalisis data produksi susu distandarkan pada 305 hari lamanya pemerahan, dua kali frekuensi pemerahan per hari, umur setara dewasa (Mature equivalent). Metode penelitian yang digunakan secara kausal komparatif, analisis statistika untuk menghitung besarnya nilai ripitabilitas produksi susu dengan korelasi dalam kelas (intra class correlation), nilai ripitabilitas produksi susu yang didapat kemudian digunakan untuk menduga daya produksi susu yaitu dengan menggunakan rumus daya produksi susu dari Lush (1979). Nilai korelasi genetik dan fenotipik antara produksi susu laktasi pertama dengan daya produksi susu digunakan analisis ragam dan peragam pola satu arah model saudara tiri sebapak. Rataan produksi susu laktasi pertama yang didapat dari hasil penelitian ini sebesar 2.919,04 kilogram, nilai ripitabilitas produksi susu sebesar 0,41, rataan daya produksi susu sebesar 2.920,23 kilogram, serta nilai korelasi genetik dan fenotipik antara produksi susu laktasi pertama dengan daya produksi susu masing-masing sebesar 0,89 dan 0,76 .
\end{abstract}

Kata kunci : Korelasi, genetik, fenotipik, laktasi pertama

\section{PENDAHULUAN}

Tujuan pemeliharaan ternak sapi perah adalah untuk mengubah bahan pakan menjadi produk yang diharapkan yaitu berupa susu. Hal ini karena susu merupakan produk utama dari sapi perah, maka semua sifat yang berhubugan dan dapat menunjang kemampuan sapi perah untuk berproduksi secara maksimal perlu diperhatikan lebih seksama. Peningkatan produktivitas sapi perah melalui perbaikan lingkungan belum cukup tetapi lebih sempurna apabila disertai dengan peningkatan mutu genetik, diantaranya melalui seleksi. Dalam hal 
ini Makin at, al., (1985) mengemukakan bahwa berhasil tidaknya peningkatan mutu genetik sangat bergantung kepada : pertama cara menentukan sapi perah yang akan digunakan yaitu yang memiliki genetik superior dan kedua bagaimana efektivitas sifat superior tersebut dapat dikembangkan lebih lanjut.

Dalam suatu program pemuliaan ternak terutama melalui seleksi, data tentang sifat-sifat yang akan diseleksi sangat diperlukan. Johansson (1961) mengemukakan bahwa langkah awal dalam program perbaikan genetik ternak adalah pencatatan produksi yang dilaksanakan dengan teratur dan lengkap serta silsilah keturunan setiap individu dicatat. Sudono dan Martojo (1977) mengemukan bahwa untuk menghitung parameter genetik dan fenotipik sifat-sifat produksi susu diperlukan sejumlah ternak yang mempunyai catatan lengkap. Beberapa sifat yang dapat dijadikan bahan pertimbangan seleksi sapi perah, diantaranya sifat produksi susu serta sifat-sifat lainnya yang berhubungan dengan produksi susu. Adanya korelasi genetik yang tinggi antara produksi susu laktasi pertama dengan produksi susu laktasi berikutnya, hal ini berarti bahwa apabila seleksi dilakukan pada produksi susu laktasi pertama akan berhasil baik terhadap produksi laktasi berikutnya. Sapi perah berproduksi tinggi pada laktasi pertama akan berproduksi tinggi pula pada laktasi berikutnya dibandingkan dengan sapi perah yang produksi susu laktasi pertama rendah. Tinggi rendahnya produksi susu laktasi pertama dapat dijadikan pegangan dalam menentukan produksi susu laktasi berikutnya, serta dapat dijadikan dasar untuk melakukan seleksi sapi perah dalam kriteria bibit pada generasi berikutnya (Bath et al., 1978). Daya produksi susu seekor sapi perah dalam suatu peternakan sering dijadikan bahan pertimbangan untuk melakukan seleksi. Seleksi berdasarkan daya produksi susu memberikan ketelitian yang lebih akurat karena ada kaitannya dengan nilai ripitabilitas. Pengukuran ternak sapi perah berdasarkan daya produksi sangat bermanfaat dan efektip untuk menentukan pilihan sapi perah yang dijadikan bibit dalam usaha peternakan (Campbell and Marshall, 1975). Lebih lanjut dikemukakan bahwa pengujian daya produksi susu sapi perah pada akhirnya dapat diperoleh informasi sampai sejauh mana program pemuliaan, pemberian makanan serta tatalaksana yang telah dilaksanakan berhasil.

Seleksi terhadap suatu sifat akan berpengaruh pada sifat yang lainnya apabila diantara sifat tersebut terdapat nilai korelasi yang besar (Hargrove et al., 1969). Dalam hal ini pendugaan nilai korelasi genetik dan fenotipik merupakan kelengkapan informasi, karena dapat digunakan untuk memperkirakan besarnya perubahan-perubahan pada generasi berikutnya bila digunakan sebagai kriteria seleksi. Pendugaan ini berguna apakah seleksi untuk satu sifat tertentu akan mempunyai pengaruh menguntungkan atau tidak terhadap sifat yang lainnya (Warwick et al., 1987). Besarnya nilai korelasi genetik dan fenotipik antara produksi susu laktasi pertama dengan daya produksi susu pada sapi perah Fies Holland berkisar antara 0,62 - 0,85 untuk korelasi genetik dan 0,29 - 0,74 untuk korelasi fenotipik (Sudono et al.., 1983).

\section{MATERI DAN METODE}

Materi penelitian adalah catatan hidup produktif sapi perah Fries Holland yang ada pada perusahaan-perusahaan di kabupaten Bandung dari tahun 2001-2004. Data yang diamati mulai tahun 2001 sampai dengan tahun 2004, selanjutnya diseleksi berdasarkan kelengkapan catatan berupa tanggal dilahirkan, tanggal berproduksi, lama produksi, dan catatan silsilahnya. Data terseleksi diperoleh 161 ekor individu sapi yang berasal dari 20 ekor pejantan, serta kemudian digunakan untuk menghitung ripitabilitas, daya produksi susu serta korelasi genetik dan fenotipik.Peubah yang diamati adalah catatan produksi susu laktasi pertama, kedua, ketiga, dan keempat dari sapi perah produktif yang telah dikoreksikan terhadap lama laktasi 305 hari, dua kali frekuensi pemerahan, dan umur setara dewasa (mature equivalent).

Syarat untuk menghitung daya produksi susu, terlebih dahulu harus diketahui nilai ripitabilitas produksi susu. Untuk maksud tersebut ripitabilitas produksi susu dianalisis dengan rancangan acak lengkap pola korelasi dalam kelas (intra class correlation) dengan 
jumlah pengamatan yang berbeda per individu menurut petunjuk Backer (1975). Daya produksi susu seekor sapi perah dihitung menggunakan rumus dari Lush (1979).Nilai korelasi genetik dan fenotipik produksi susu laktasi pertama dengan daya produksi susu yang diduga menggunakan rancangan acak lengkap dengan analisis keragaman dan peragam menurut petunjuk Becker (1979).

\section{HASIL DAN PEMBAHASAN}

\section{Produksi Susu}

Produksi susu sapi perah Fries Holland dari hasil penelitian dapat dilihat pada Tabel 1 .

Tabel 1. Produksi susu sapi perah Fries Holland pada perusahaan-perusahaan di kabupaten Bandung

\begin{tabular}{lccc}
\hline \multicolumn{1}{c}{ Periode laktasi } & $\begin{array}{c}\text { Jumlah sapi perah } \\
\text { (ekor) }\end{array}$ & $\begin{array}{c}\text { Rataan produksi susu } \\
\text { (kilogram) }\end{array}$ & $\begin{array}{c}\text { Simpangan baku } \\
\text { (kilogram) }\end{array}$ \\
\hline Laktasi pertama & 161 & $2.919,04$ & 562,96 \\
Laktasi kedua & 160 & $2.934,29$ & 572,61 \\
Laktasi ketiga & 148 & $2.969,83$ & 690,50 \\
Laktasi keempat & 77 & $2.766,60$ & 400,88 \\
Jumlah & 546 & $2.917,92$ & 873,32 \\
Rataan & 546 & $2.917,92$ & 873,32 \\
\hline
\end{tabular}

Pada Tabel 1 dapat dilihat bahwa rataan produksi susu laktasi pertama pada perusahaan-perusahaan di kabupaten Bandung sebesar 2.917,04 $\pm 562,96$ kilogram. Rataan produksi susu laktasi pertama bila dibandingkan dengan rataan produksi susu sapi perah Fries Holland yang dilaporkan Sudono, et. al. (1983) sebesar 2.558,30 - 3.494,98 kilogram dan Makin (1983) sebesar 2.646,39 4.789,03 kilogram, hal ini ternyata masih termasuk dalam kisaran produksi susu laktasi pertama kedua peneliti tersebut. Produksi susu laktasi pertama sapi perah pada perusahaanperusahaan di kabupaten Bandung cukup baik. Namun demikian, bila dibandingkan dengan produksi susu laktasi pertama sapi perah Fries Holland di Kanada sebesar 4.896,00 kilogram (Hoque and Hodges, 1980), ternyata produksi susu laktasi pertama pada perusahaan di Bandung termasuk rendah. Rendahnya produksi susu laktasi pertama pada perusahaan tersebut dibandingkan di daerah sedang disebabkan oleh mutu genetick sapi perah yang lebih rendah serta keadaan lingkungan yang kurang baik. Hal tersebut juga dikemukakan Yousef (1982) bahwa sapi perah Fries Holland di daerah tropis produksi susunya lebih rendah bila dibandingkan dengan di daerah sedang, keadaan tersebut disebabkan mutu pakan rendah, tatalaksana yang belum baik serts mutu genetik ternak yang masih rendah.

Produksi susu sapi perah Fries Holland pada perusahaan ini untuk setiap periode laktasi ternyata lebih rendah bila dibandingkan dengan produksi susu sapi perah Fries Holland hasil penelitian Miller et. al. (1976) yaitu sebesar 5.657,00; 5.789,00; 5.893,00; dan 5.893,00 kilogram masing-masing untuk laktasi pertama, kedua, ketiga, dan keempat. Rendahnya produksi susu di daerah tropis pada setiap laktasinya bila dibandingkan dengan produksi susu di daerah subtropis, diduga disebabkan faktor pemberian pakan, tatalaksana, program pemuliaan dan kontrol penyakit yang belum baik disamping pengaruh musim di tropis.

\section{Daya Produksi Susu}

Hasil analisis besarnya dugaan daya produksi susu sapi perah Fries Holland pada perusahaan-perusahaan ini dengan menggunakan data produksi susu 546 catatan produksi susu dari 161 ekor sapi perah sebesar 2.920,93 kilogram. Besarnya daya produksi 
susu ditentukan oleh besarnya rataan produksi susu peternakan, rataan produksi susu individu, besarnya nilai ripitabilitas, dan banyaknya laktasi dari individu yang akan dievaluasi.

Nilai ripitabilitas produksi susu sapi perah FH dari hasil penelitian menunjukkan sebesar 0,41. Hal ini berarti kemampuan ternak sapi perah FH pada perusahaan-perusahaan untuk mengulangi sifat produksi susu dari laktasi ke laktasi sebesar 41 persen dipengaruhi Faktor genetik dan lingkungan yang permanen. Variasi produksi susu setiap laktasi dipengaruhi facktor lingkungan yang bersifat sementara dan facktor lain yang belum dapat ditentukan sebesar 59 persen. Nilai ripitabilitas tersebut termasuk dalam kisaran nilai ripitabilitas produksi susu yang dikemukakan Warwick, et. al. (1987) yaitu sebesar 0,40 0,60.Perbedaan nilai ripitabilitas produksi susu sapi perah Fries Holland yang didapat dari hasil penelitian ini dengan nilai ripitabilitas produksi susu ditempat lain baik didalam negeri maupun diluar negeri, diduga disebabkan kondisi peternakan yang berbeda, jumlah catatan dan waktu pencatatan produksi yang berbeda, sebagaimana yang dikemukakan Lasley (1978) bahwa besarnya nilai ripitabilitas dipengaruhi pada jumlah catatan yang digunakan metode perhitungan, tempat, dan waktu pencatatan. Daya produksi susu sapi perah Fries Holland hasil penelitian pada perusahaan-perusahaan tersebut dibandingkan dengan daya produksi susu sapi perah Fries Holland hasil penelitian Ibrahim (1978) sebesar 2.435,00 kilogram dan tertinggi hasil penelitian Makin (1983) sebesar 4.793,33 kilogram, ternyata termasuk ke dalam kisarannya.

Berbeda bila dibandingkan dengan besarnya daya produksi susu sapi perah Fries Holland di daerah subtropis sebesar 6.000,00 kilorgam (McDowell,1987), ternyata lebih rendah hasil penelitian ini. Perbedaan besarnya daya produksi susu ini diduga disebabkan perbedaan mutu genetik dan kondisi peternakan baik dalam hal pemberian pakan, tingkat tatalaksana maupun kontrol penyakit.

\section{Korelasi Genetik dan Fenotipik}

Nilai korelasi genetik produksi susu laktasi pertama dengan daya produksi susu dari hasil penelitian ini sebesar 0,89. Hal ini berarti bahwa produksi susu laktasi pertama pada keturunannya secara genetik menentukan terhadap daya produksi susu sebesar 89 persen dan 11 persen ditentukan diluar faktor genetik. Nilai korelasi tersebut termasuk dalam kategori tinggi menurut kategori Warwick et. al., (1987) yaitu lebih besar dari 0,50. Adanya nilai korelasi genetik yang tinggi antara produksi susu laktasi pertama dengan daya produksi susu, hal ini berarti bahwa kapasitas genetik untuk produksi susu tinggi akan selalu dipertahankan individu sapi perah tersebut sampai mencapai usia tua. Dengan demikian sapi perah yang menunjukkan produksi susu laktasi pertama tinggi secara genetik akan memperlihatkan daya produksi susu yang tinggi pula.

Nilai korelasi genetik hasil penelitian ini lebih besar bila dibandingkan dengan kisaran nlai korelasi genetik antara produksi susu laktasi pertama dengan daya produksi susu yang dilaporkan oleh Sudono, et. al. (1983) yaitu berkisar antara 0,62-0,85. Perubahan ini diduga disebabkan jumlah catatan yang digunakan dalam perhitungan, perbedaan kondisi peternakan dan cara perhitungan. Nilai korelasi fenotipik antara produksi susu laktasi pertama dengan daya produksi susu hasil penelitian ini sebesar 0,76. Artinya bahwa penampilan daya produksi susu sapi perah Fries Holland 76 persen ditentukan oleh variasi produksi laktasi pertama. Nilai korelasi tersebut termasuk dalam kategori tinggi berdasarkan kategori Warwick et al ., (1987).

Besarnya nilai korelasi fenotipik antara produksi susu laktasi pertama dengan daya produksi susu bila dibandingkan dengan korelasi genetik, ternyata korelasi genetik lebih besar dibandingkan dengan nilai korelasi fenotipik. Hal ini berarti bahwa potensi gentik untuk berproduksi susu pada laktasi pertama tidak ditampilkan seluruhnya pada daya produksi susu yang disebabkan perubahan lingkungan bersifat sementara. Sebagaimana yang dikemukakan Bath et al., (1978) bahwa kapasitas genetik untuk berproduksi susu tinggi akan selalu dipertahankan individu sapi perah sampai mencapai usia tua selama faktor lingkungan tidak berubah. Scmidt and Van Vleck (1974) mengemukakan faktor lingkungan dapat menghalangi kemampuan genetik dari seekor sapi perah betina untuk berproduksi susu. 
Nilai korelasi fenotipik antara produksi susu laktasi pertama dengan produksi susu hasil penelitian ini bila dibandingkan dengan nilai korelasi fenotipik antara produksi susu laktasi pertama dengan daya produksi susu hasil penelitian Sudono et al., (1983) yaitu berkisar antara 0,29 - 0,74, ternyata hasil penelitian ini lebih besar. Perbedaan ini diduga disebabkan perbedaan dari jumlah data yang dipergunakan serta kondisi peternakan. Berdasarkan uraian korelasi genetik dan fenotipik antara produksi susu laktasi pertama dengan daya produksi susu, maka dapat dinyatakann bahwa seleksi terhadap sapi perah dapat dilakukan berdasarkan produksi susu laktasi pertama serta diikuti dengan perbaikan keadaan lingkungan yang bersifat sementara, seperti makanan dan tatalaksana

\section{SIMPULAN.}

Berdasarkan hasil yang diperoleh dalam penelitian ini dapat diambil beberapa kesimpulan sebagai berikut : (1). Rataan produksi susu laktasi pertama dan daya produksi susu sapi perah Fries Holland pada perusahaan-perusahaan masing-masing sebesar 2.919,04 \pm 562,96 kilogram dan 2.920,93 kilogram. (2). Nilai korelasi genetik dan fenotipik produksi susu laktasi pertama dengan daya produksi susu masing-masing sebesar 0,89 dan 0,76 .

\section{DAFTAR PUSTAKA}

Bath, D.L., F.N. Dickinson, H.A. Tucker, and R.D. Appleman. 1978. Dairy Cattle Principles, Practices, Problems and Profits. Second Edition. Lea and Fabringer.

Becker, W.A. 1975. Manual of Procedures in quantitative Genetics. Third Edition. Washington State University Press. Washington State University Pullman Washington USA.

Campbell, J.R. and R.T. Marshall. 1975. The Science of Providing Milk Man. Mc Graw Hill Book Co. New York. USA.

Hargrove, G.L., J.J. Salazar, and J.E. Legates. 1969. Relationships Among Frist Lactation and Lifetime Measurements in Dairy Population. J. Dairy Sci. 52:651-656.
Hoque, M. and J. Hodges. 1980. Genetic and Phenotypic Parameters of Lifetime Production Traits in Holstein Lows. J.Dairy Sci. 63: 19001910.

Lee, A.J. and C.R. Herderson. 1972. Effect of Cow on Repeatability Estimates. J. Animal Sci. 32:167173.

Lush, J.L. 1979. Animal Breeding Plams. The Iowa State University Press. Ames. Iowa.USA.

Makin, M., E. Sukraeni, W. Djaja, N. Kasim, I. Hamidah, dan I.B. Suamba. 1985. Korelasi Genetik dan Fenotipik Sifat-sifat Reproduksi dan Produksi Air Susu Sapi Perah Fries Hollands di Jawa Barat. Laporan Penelian. Fakultas Peternakan Universitas Padjadjaran. Bandung.

Mc Intyre, K.H. 1971. Milk Production From Bos Taurus Dairy Cows in Fiji. Trop. Agric. 48:317326.

Mekir, W.S. 1982. Parameter Fenotipik dan Genetik Sifat-sifat Reproduksi dan Produksi Sapi Perah Fries Holland di beberapa Perusahaan Peternakan. Laporan penelitian. IPB.

Miller, R.H., R.E. Pearson, B.T. Weinland, and L.A. Fulton. 1976. Genetic Parameters of Several Measures of Milk Flow Rate and Milking Time. J. Dairy Sci. 59:957-964.

Sudono, A. dan H. Martojo. 1977. Program Pemuliaan Sapi Perah. Direktorat Jenderal Peternakan. Departemen Pertanian Republik Indonesia. Jakarta.

Sudono, A., H. Martojo, dan W.Sumudhita. 1983. Parameter Fenotipik dan Genetik Sifat-sifat Produksi Sapi Perah Fries Holland Pada Perusahaan-perusahaan Peternakan. Proceding. Pertemuan Ilmiah Ruminansia Besar. Pusat Penelitian dan Pengembangan Peternakan Departemen Pertanian. Jakarta.

Warwick, E.J., J.M. Astuti, dan W. Hardjosubroto. 1987. Pemuliaan Ternak. Gadjah Mada University Press.

Yousef, M.K. 1982. Animal Product in The Tropics. Preager Special Studies-Preager Scitipik

Jurnal Sain Peternakan Indonesia Vol. 2, No 1, Januari - Juni 2007 
